\title{
Analisis Perbandingan Perhitungan Volume Bersih Galian dan Timbunan (Net Volume) dengan Metode Trapezoidal dan Borrow Pit pada Perangkat Lunak Autocad Civil 3D
}

\author{
Analysis the Difference of Net Volume Calculation Using Trapezoidal and Borrow Pit Method in the Autocad Civil \\ 3d Software)
}

\author{
M. Ubayu Rizqi Rohmat Tulloh', Yuwono*2, Akbar Kurniawan*3 \\ ${ }^{1,2,3}$ Departemen Teknik Geomatika, FTSLK-ITS, Kampus ITS Sukolilo, Surabaya, 60111, Indonesia \\ *Korespondensi penulis: yuwono@geodesy.its.ac.id ${ }^{2}$, akbar@geodesy.its.ac.id ${ }^{3}$
}

Diterima: 14082020; Diperbaiki: 09092020; Disetujui: 16092020; Dipublikasi: 21012021

\begin{abstract}
Abstrak: Dalam dunia pertambangan batu bara dikenal istilah joint survey. Dalam joint survey yang digunakan parameter pembayaran oleh owner kepada kontraktor adalah volume bersih galian dan timbunan (net volume), oleh karena itu harus diukur dan dihitung dengan metode maupun perangkat lunak yang sesuai. Saat ini perangkat lunak sebagai penunjang kegiatan pertambangan semakin berkembang, berbagai perangkat lunak memiliki kekurangan dan kelebihan tersendiri. Pada penelitian kali ini akan melakukan perhitungan volume bersih galian dan timbunan (net volume) dengan data dari salah satu pit di area tambang PT Anugerah Bara Kaltim yang dipotong menjadi 3 bagian yaitu pit bagian $\mathrm{A}, \mathrm{B}$, dan $\mathrm{C}$, perhitungan volume dilakukan dengan menggunakan metode Trapezoidal dan Borrow Pit pada perangkat lunak AutoCAD Civil 3D dimana dari hasil tiap metode akan dibandingkan terhadap nilai hitungan manual sebagai acuan dengan mengacu pada toleransi ASTM (American Society for Testing and Materials) pada tahun 2002 yaitu batas maksimal prosentase selisih hasil perhitungan volume yaitu sebesar $2,78 \%$, selanjutnya akan dianalisa manakah metode yang tepat untuk digunakan dalam pekerjaan perhitungan volume tambang batubara. Pada proses perhitungan volume diberikan 2 perlakuan, yaitu dengan merubah interval section untuk metode trapezoidal dan merubah interval grid untuk metode borrow pit, dari hasil perhitungan volume didapatkan rata-rata nilai selisih volume yang beragam, yaitu pada metode borrow pit sebesar 1,911\%, dan metode trapezoidal sebesar 0,427\%. Pada perhitungan metode trapezoidal, semakin kecil interval section yang dibuat maka hasil perhitungan akan semakin mendekati volume acuan. Pada perhitungan metode borrow pit, semakin kecil interval grid yang dibuat maka hasil perhitungan akan semakin mendekati volume acuan.
\end{abstract}

Copyright $\odot 2020$ Geoid. All rights reserved.

\begin{abstract}
In the world of coal mining, the term joint survey is known. In the joint survey, the parameter of payment by the owner to the contractor is used as net volume, therefore, it must be measured and calculated by the appropriate method. Currently, software that supports mining activities is growing. Various software have their own advantages and disadvantages. In this research, we will calculate the net volume with data from one of the pits in the mining area of PT Anugerah Bara Kaltim which is cut into 3 parts, namely pits A, B, and $C$, the volume calculation is done using the Trapezoidal and Borrow Pit methods on the device. AutoCAD Civil 3D software where the results of each method will be compared to the manual count value as a reference with reference to the tolerance of ASTM (American Society for Testing and Materials) in 2002, which is the maximum percentage difference in volume calculation results, which is $2.78 \%$, then it will analyzed which method is appropriate to use in the work of calculating the volume of coal mines. In the volume calculation process, 2 treatments were given, namely by changing the section interval for the trapezoidal method and changing the grid interval for the borrow pit method, from the volume calculation results obtained the average value of various volume differences, namely the borrowpit method of $1.911 \%$, and the trapezoidal method. by $0.427 \%$. In the calculation of the trapezoidal method, the smaller the section interval made, the calculation results will be closer to the reference volume. In the calculation of the borrow pit method, the smaller the grid interval that is made, the calculation results will be closer to the reference volume.
\end{abstract}

Kata kunci : Borrow Pit; Net Volume; Trapezoidal 


\section{Pendahuluan}

Pekerjaan tambang seperti pengukuran topografi, staking out, penentuan batas penambangan (boundary) dan perhitungan jumlah volume galian merupakan bidang pekerjaan yang berhubungan dengan disiplin ilmu Teknik Geomatika (Oktavian A. 2008). Dalam dunia pertambangan batu bara dikenal istilah joint survey, yaitu proses pengukuran dan perhitungan galian tambang yang dilakukan bersama-sama antara kontraktor dan owner tambang. Dalam joint survey yang digunakan parameter pembayaran oleh owner kepada kontraktor adalah volume bersih galian dan timbunan atau net volume, oleh karena itu volume bersih galian dan timbunan harus diukur dan dihitung dengan metode maupun perangkat lunak yang sesuai.

Perangkat lunak yang digunakan dalam bidang pertambangan sebagai alat penunjang pengolahan data seperti penghitungan volume kini semakin banyak ditemui, seperti minescape, surpac vision, 12d, Terramodel, AutoCAD Civil $3 D$ dan sebagainya. Dengan adanya perkembangan teknologi informasi yang sangat pesat, berpengaruh pada perkembangan perangkat lunak, beberapa perangkat lunak dapat memiliki lebih dari 1 metode untuk penghitungan volume.

Penelitian kali ini akan melakukan penghitungan volume galian batu bara dengan data dari salah satu pit di area tambang PT Anugerah Bara Kaltim, menggunakan metode Trapezoidal dan Borrow Pit pada perangkat lunak AutoCAD Civil 3D (Student Version) dimana dari hasil perhitungan volume tiap metode akan dianalisa manakah metode yang tepat untuk digunakan dalam pekerjaan perhitungan volume galian tambang batubara. Analisa dilakukan dengan menghitung nilai persentase selisih perhitungan volume yang dilakukan pada metode Trapezoidal dan Borrow Pit pada perangkat lunak AutoCAD Civil 3D terhadap hitungan manual dengan metode borrow pit.

Penelitian terdahulu yang pertama yaitu, Penelitian dilakukan oleh Aditiya Oktavian pada tahun 2008 dengan judul Analisis Perbandingan Software Surpac Vision V4.1-J dan Surfer 8.0 Pada Perhitungan Volume Galian Dan Timbunan Tambang. Tujuan dari penelitian tersebut adalah membandingkan hasil perhitungan volume galian dan timbunan tambang pada dua perangkat lunak yaitu Surpac Vision V4.1-J dan Surfer 8.0 dan sebagai nilai acuan perhitungan volume menggunakan perhitungan manual dengan metode Borrow Pit. Analisa yang dilakukan adalah Analisa terhadap hal-hal yang dapat mempengaruhi hasil perhitungan tersebut. Hasil dari penelitian tersebut berupa hasil perhitungan volume pada perangkat lunak Surpac Vision V4.1-J dan Surfer 8.0 dan nilai selisih hasil perhitungan volume antara kedua perangkat lunak tersebut terhadap nilai acuan perhitungan volume.

Lalu penelitian sebelumnya yang lain dilakukan oleh Irfan Maulana Yusuf pada tahun 2018 dengan judul Analisis Volume Pengerukan Alur Pelayaran Barat Surabaya Dengan Data Multibeam Echosounder Menggunakan Perangkat Lunak Hypack Dan AutoCAD Civil 3D. Penelitian tersebut bertujuan untuk mendapatkan peta batimetri alur pelayaran barat Surabaya dari data multibeam echosounder dan menganalisis volume pengerukan alur pelayaran barat Surabaya dari data eksisting terhadap rencana dengan menggunakan perangkat lunak Hypack Dan AutoCAD Civil $3 D$ dengan dibandingan dengan nilai hitungan manual metode cross section sebagai nilai acuan . hasil dari penelitian tersebut adalah peta batimetri alur pelayaran barat Surabaya dengan skala 1:150.000 dan hasil perhitungan volume pengerukan Alur Pelayaran Barat Surabaya menggunakan perangkat lunak AutoCAD Civil 3D dan Hypack dan nilai selisih terhadap hitungan manual.

Perbedaan yang dilakukan dalam penelitian ini dengan penelitian yang sudah dilakukan sebelumnya yakni bertujuan membandingkan hasil penghitungan volume bersih galian dan timbunan tambang batu bara antara metode Trapezoidal dan Borrow Pit pada perangkat lunak AutoCAD Civil 3D dan mengetahui pengaruh nilai interval grid dan interval section terhadap hasil perhitungan volume. Sebagai nilai acuan hasil penghitungan volume menggunakan penghitungan volume manual dengan metode borrow pit. Pada penelitian ini juga menggunakan data pit tambang pada salah satu pit milik PT Anugerah Bara Kaltim yang dipotong menjadi 3 bagian sebagai nilai pembanding. Analisa yang dilakukan dengan menghitung selisih perhitungan volume masing-masing metode pada setiap perangkat lunak yang mengacu pada nilai toleransi ASTM (American Society for Testing and Material) yaitu batas maksimal prosentase selisih hasil perhitungan volume adalah 
sebesar 2,78\%. Dari analisa tersebut akan diambil sebuah rekomendasi penggunaan metode yang tepat untuk pekerjaan tambang batu bara.

\section{Data dan Metode}

Data yang digunakan dalam penelitian ini adalah Data hasil pekerjaan tambang di salah satu Pit pada area tambang PT Anugerah Bara Kaltim, dimana data diambil dengan menggunakan Total Station Sokkia Set $2 X$. Data berupa koordinat detail $(\mathrm{X}, \mathrm{Y}, \mathrm{Z})$ dan koordinat $(\mathrm{X}, \mathrm{Y}, \mathrm{Z})$ alignment atau baseline (sebagai acuan perhitungan volume metode trapezoidal). Peralatan yang digunakan adalah perangkat lunak dan perangkat keras. Perangkat lunak yang digunakan adalah AutoCAD Civil 3D dan Matlab. Perangkat keras terdiri dari laptop dan mouse.

Lokasi yang digunakan dalam penelitian ini adalah pada salah satu Pit di area tambang PT Anugerah Bara Kaltim yang terletak di Jl. Raya Bakungan, Kec. Loa Janan, Bakungan, Kec. Loa Janan, Kabupaten Kutai Kartanegara, Kalimantan Timur 75391 (0 40' 57,88"- $0^{\circ} 40^{\prime}$ 05,22" LS dan $117^{\circ} 03^{\prime} 38,11^{\prime \prime}-117^{\circ} 04^{\prime} 26,09^{\prime \prime}$ BT).
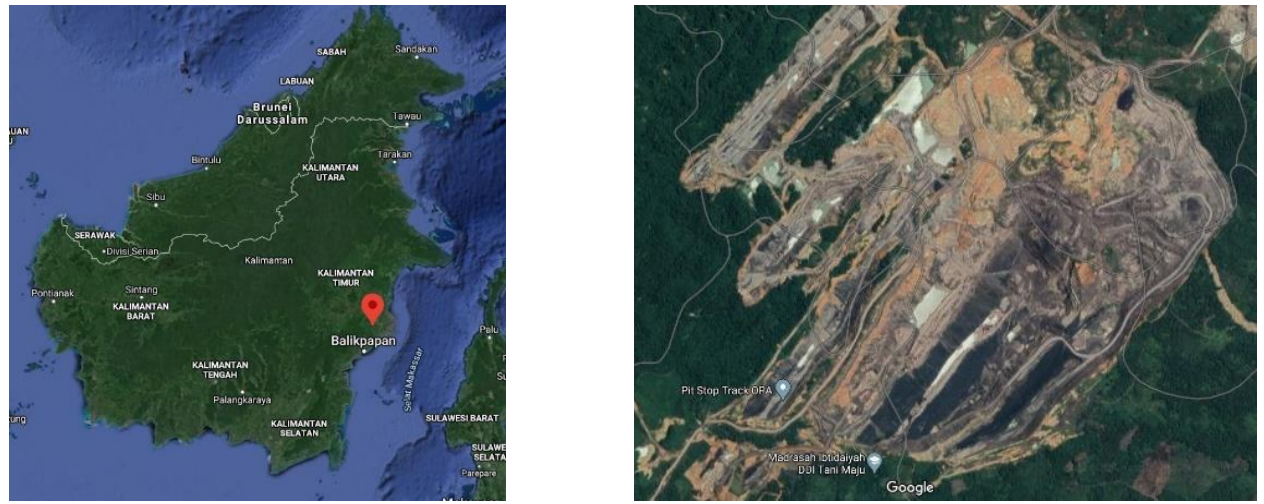

Gambar 1. Gambar Lokasi Penelitian (Google Earth,2019)

Pada tahapan pengolahan data terdiri dari pengolahan data topografi hasil pengukuran dan perhitungan volume tiap metode pada perangkat lunak AutoCAD Civil 3D, kemudian dilakukan analisa yaitu dengan menghitung prosentase selisih perhitungan volume terhadap data pembanding dengan mengacu pada toleransi ASTM (American Society for Testing and Material) yaitu batas maksimal prosentase selisih hasil perhitungan volume adalah sebesar $2,78 \%$.

Pada perhitungan volume metode Borrow Pit AutoCAD Civil 3D, Perhitungan ini dilakukan dengan membuat 2 surface, yaitu surface natural dan end of month, kemudian input data koordinat natural dan end of month. Kemudian dilakukan penghitungan volume metode Borrow pit dengan fitur yang sudah tersedia pada perangkat lunak.

Pada Pehitungan volume metode Trapezoidal AutoCAD Civil 3D, Perhitungan ini dilakukan dengan membuat 2 surface, yaitu surface natural dan end of month, kemudian input data koordinat natural dan end of month, setelah itu dibuat alignment atau baseline sebagai garis acuan untuk membuat section, lalu dibuat section dari alignment yang sudah dibuat, kemudian dilakuakan penghitungan volume metode Trapezoidal dengan fitur yang sudah tersedia pada perangkat lunak.

Pada Penghitungan Volume Manual Pada Perangkat Lunak Matlab dilakukan dengan diimport data dan plotting koordinat data natural dan eom. Data koordinat berbentuk X, Y, dan Z akan interpolasi untuk mendapatkan data tambahan dari data yang sudah ada, interpolasi dilakukan dua kali, yaitu pada koordinat x,y (sebagai titik kueri pada interpolasi koordinat z) dan pada koordinat z, interpolasi pada koordinat x,y dilakukan dengan menggunakan perintah meshgrid yaitu dengan tujuan menghasilkan grid-grid dengan titik-titik yang 
berjarak atau spasi sama atau seragam, jarak grid yang digunakan dalam penelitian ini adalah 10 meter sesuai dengan jarak pengambilan data dilapangan, selanjutnya dilakukan interpolasi pada koordinat $\mathrm{z}$ dengan menggunakan perintah griddata, dengan metode interpolasi yang digunakan adalah interpolasi linier sebab keadaan dilapangan bentuk lokasi tambang adalah relatif linier atau mendatar. Interpolasi menggunakan perintah griddata akan menginterpolasi nilai z pada titik kueri $\mathrm{x}$ dan y hasil dari proses meshgrid, Proses selanjutnya adalah melakukan sortir atau pengelompokan nilai z sesuai dengan prinsip perhitungan volume metode borrow pit, yaitu h1, h2, h3 dan h4, kemudian dilakukan perhitungan volume menggunakan rumus berikut :

$$
\mathrm{V}=\frac{A}{4}\left(1 \sum h 1+2 \sum h 2+3 \sum h 3+4 \sum h 4\right)
$$

\section{Hasil dan Pembahasan}

Pada penelitian kali ini menggunakan data 1 pit yang dipotong menjadi 3 bagian yang dimisalkan pit A,pit B, dan pit C. Berdasarkan hasil pengolahan diatas didapat beberapa hasil yaitu sebaran data koordinat natural (sebagai upper surface) dan eom sebagai (lower surface), hasil bentukan DTM natural dan eom pada perangkat lunak AutoCAD Civil 3D dan Matlab, hasil perhitungan volume bersih galian dan timbunan (Net Volume) dengan metode trapezoidal dan borrow pit pada perangkat lunak AutoCAD Civil $3 D$ dan dan hasil perhitungan volume manual dengan metode borrow pit pada perangkat lunak Matlab. Berikut merupakan hasil dari penelitian kali ini :

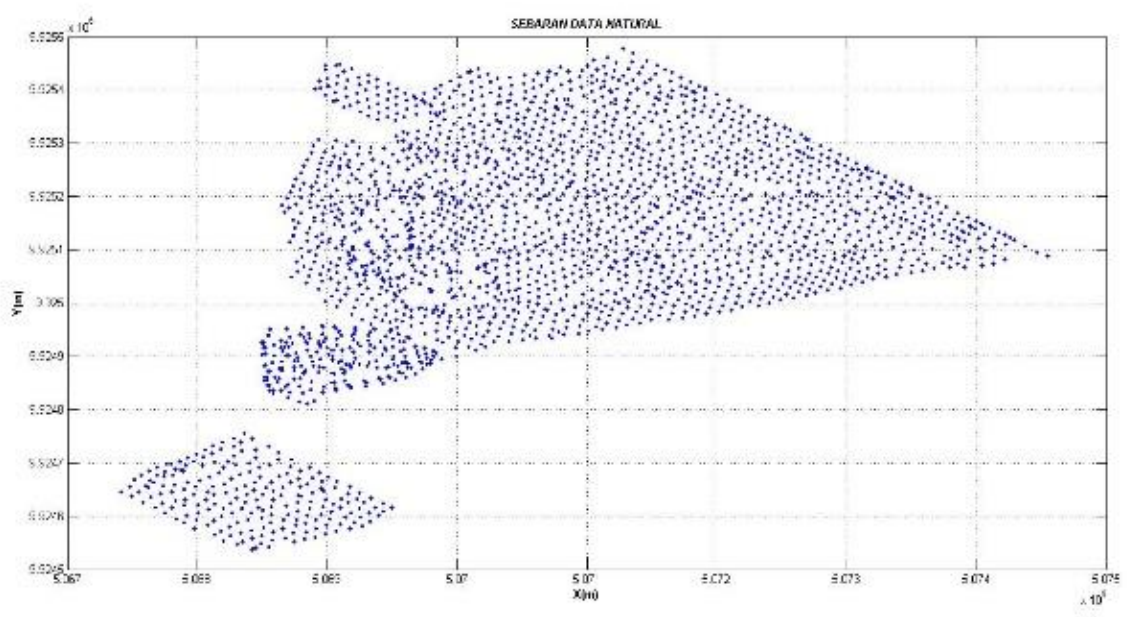

(a)

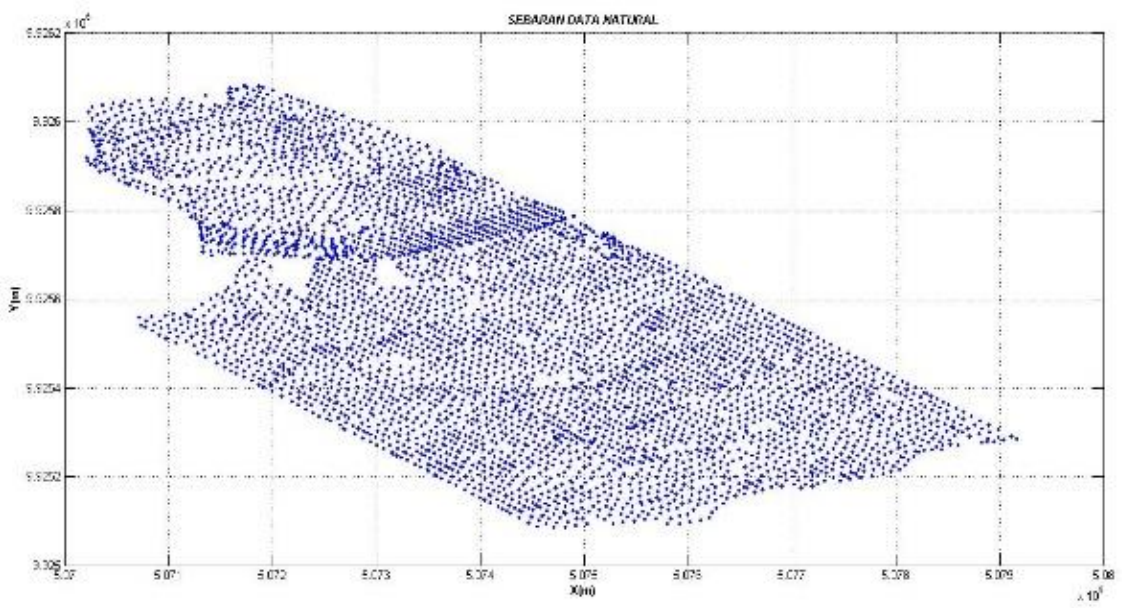

(b) 


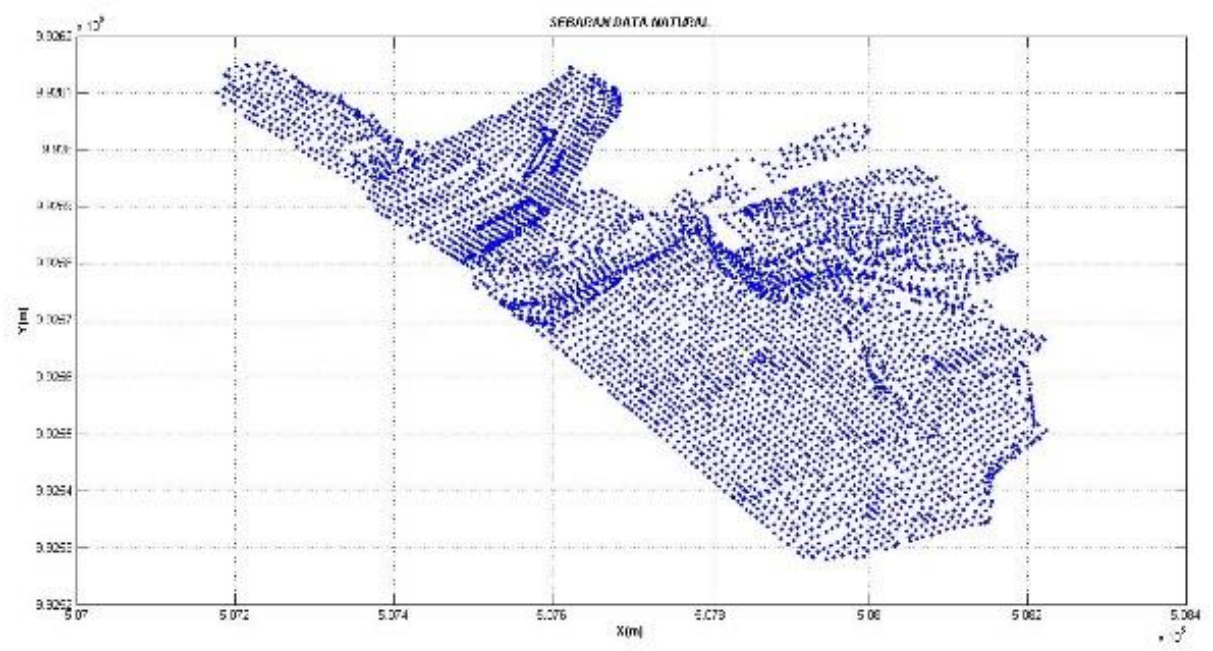

(c)

Gambar 2. Sebaran Data Natural

(Keterangan: notasi titik “.” Pada label diatas adalah sebagai koma “,”)

Gambar 2 memperlihatkan sebaran data pit natural yang di potong menjadi 3 bagian yaitu pit A, pit B, dan Pit C, dengan luas masing-masing bagian adalah pit A 22,497 Ha, pit B 26,642 Ha dan pit C 23,662 Ha, dengan statistik koordinat ditampilkan pada tabel sebagai berikut:

Tabel 1. Statistik data natural Pit A

\begin{tabular}{lll}
\hline \multicolumn{3}{c}{ Pit A } \\
\hline Titik & Minimum & Maksimum \\
\hline $\mathrm{X}$ & $506.741,2 \mathrm{~m}$ & $507454,7 \mathrm{~m}$ \\
$\mathrm{Y}$ & $9.924 .536 \mathrm{~m}$ & $9.925 .478 \mathrm{~m}$ \\
$\mathrm{Z}$ & $82,229 \mathrm{~m}$ & $118,524 \mathrm{~m}$ \\
\hline \multicolumn{3}{c}{ Jumlah Titik $: 2.361$}
\end{tabular}

Tabel 2. Statistik data natural Pit B

\begin{tabular}{lll}
\hline \multicolumn{3}{c}{ Pit B } \\
\hline Titik & Minimum & Maksimum \\
\hline $\mathrm{X}$ & $507021,5 \mathrm{~m}$ & $507916,8 \mathrm{~m}$ \\
$\mathrm{Y}$ & $9.925 .085 \mathrm{~m}$ & $9.926 .081 \mathrm{~m}$ \\
$\mathrm{Z}$ & $60,391 \mathrm{~m}$ & $122,477 \mathrm{~m}$ \\
\hline
\end{tabular}

Jumlah Titik : 4.594

Tabel 3. Statistik data natural Pit C

\begin{tabular}{lrr}
\hline \multicolumn{3}{c}{ Pit C } \\
\hline Titik & Minimum & \multicolumn{1}{c}{ Maksimum } \\
\hline $\mathrm{X}$ & $507178,4 \mathrm{~m}$ & $508224,3 \mathrm{~m}$ \\
$\mathrm{Y}$ & $9.925 .279 \mathrm{~m}$ & $9.926 .153 \mathrm{~m}$ \\
$\mathrm{Z}$ & $47,579 \mathrm{~m}$ & $131,156 \mathrm{~m}$ \\
\hline \multicolumn{3}{c}{ Jumlah Titik $: 5.296$} \\
\hline
\end{tabular}


Tabel 1, 2, dan 3 menampilkan statistik koordinat pada masing-masing pit potongan, yaitu koordinat $\mathrm{X}$ minimum dan maksimum, koordinat $\mathrm{Y}$ minimum dan maksimum, koordinat $\mathrm{Z}$ minimum dan maksimum dan jumlah seluruh titik koordinat.

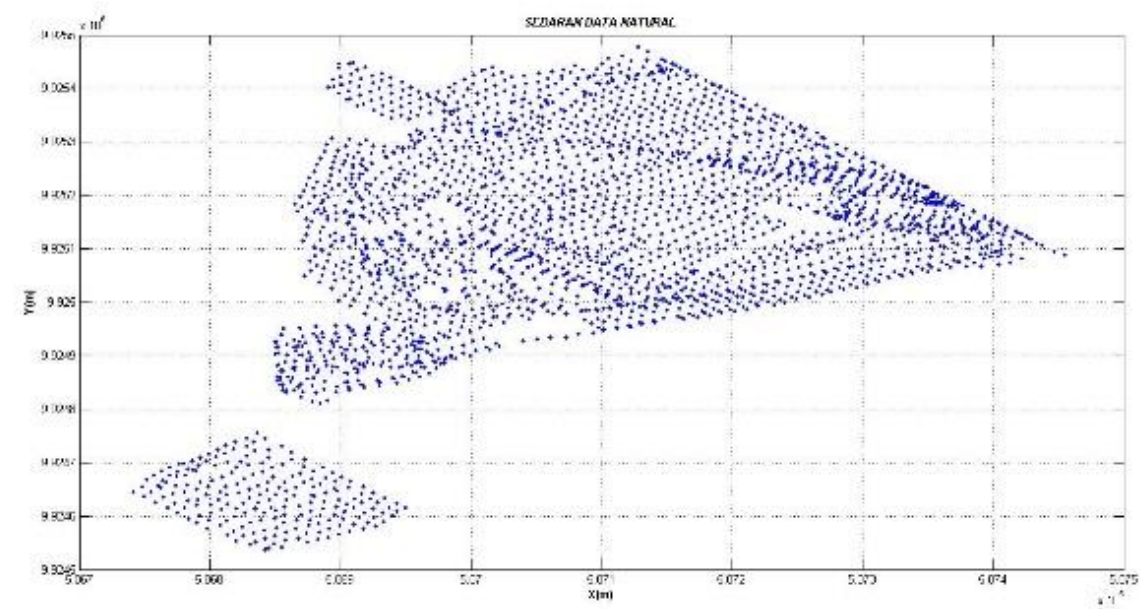

(a)

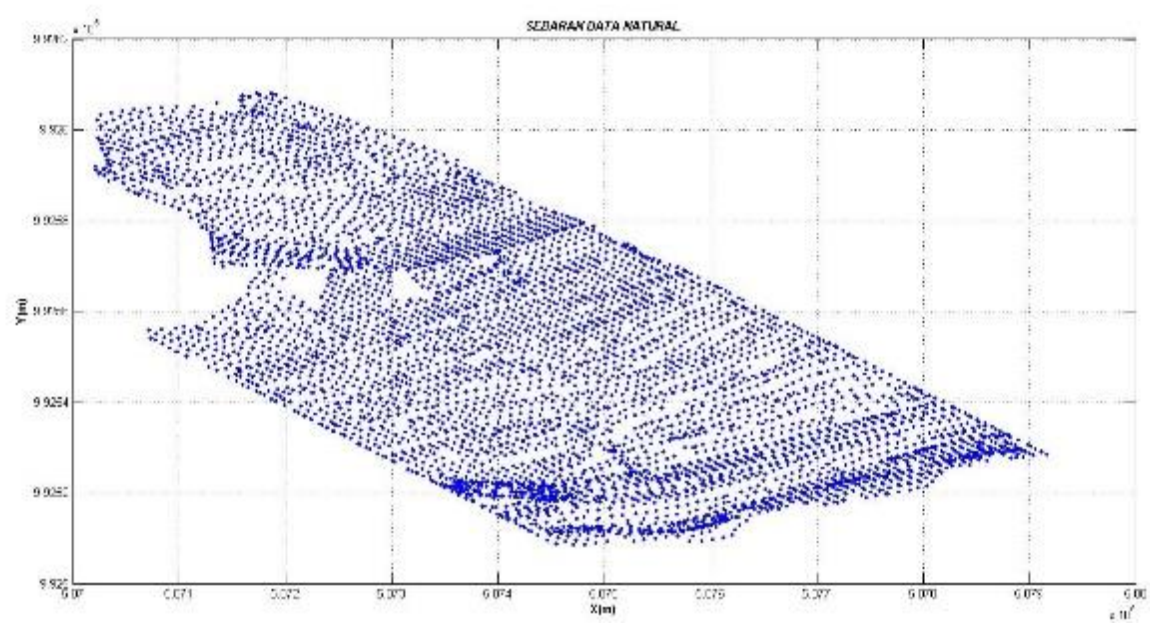

(b)

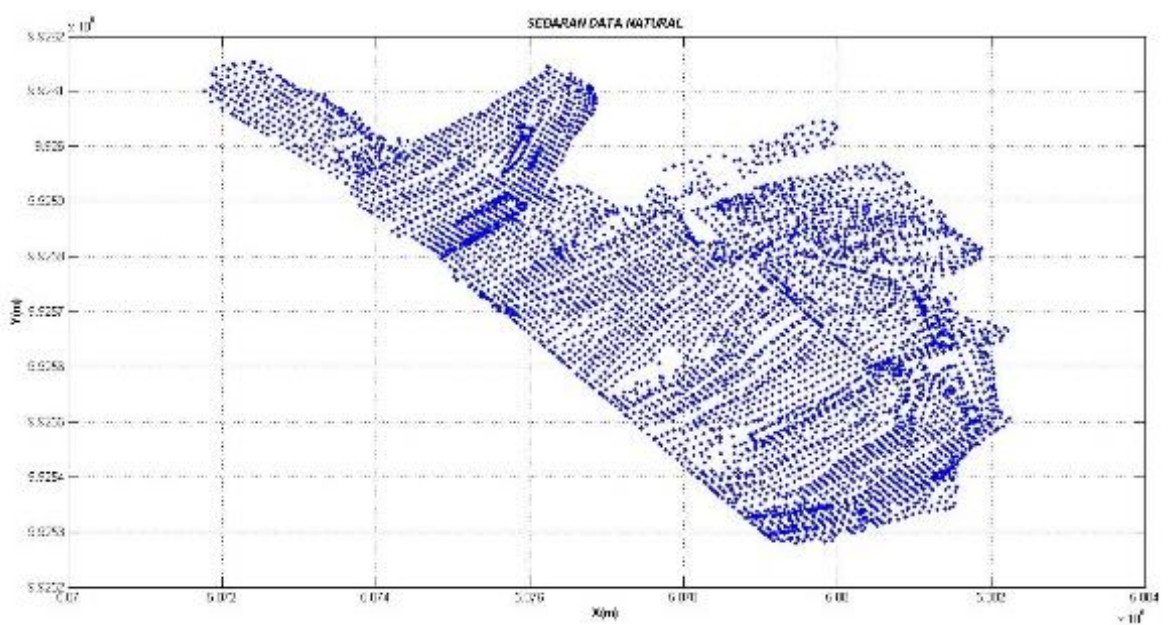

(c)

Gambar 3. Sebaran Data EOM

(Keterangan: notasi titik “.” Pada label diatas adalah sebagai koma “,”) 
Gambar 3 memperlihatkan sebaran data pit EOM yang di potong menjadi 3 bagian yaitu pit A, pit B, dan Pit C, dengan luas masing-masing bagian adalah pit A 22,497 Ha, pit B 26,642 Ha dan pit C 23,662 Ha, dengan statistik koordinat ditampilkan pada tabel sebagai berikut:

Tabel 4. Statistik data EOM Pit A

\begin{tabular}{lll}
\hline \multicolumn{3}{c}{ Pit A } \\
\hline Titik & Minimum & Maksimum \\
\hline $\mathrm{X}$ & $506.741,2 \mathrm{~m}$ & $507454,7 \mathrm{~m}$ \\
$\mathrm{Y}$ & $9.924 .536 \mathrm{~m}$ & $9.925 .478 \mathrm{~m}$ \\
$\mathrm{Z}$ & $82,229 \mathrm{~m}$ & $118,524 \mathrm{~m}$ \\
\hline \multicolumn{3}{c}{ Jumlah Titik $: 2.361$} \\
\hline
\end{tabular}

Tabel 5. Statistik data EOM Pit B

\begin{tabular}{lll}
\hline \multicolumn{3}{c}{ Pit B } \\
\hline Titik & Minimum & Maksimum \\
\hline $\mathrm{X}$ & $507021,5 \mathrm{~m}$ & $507916,8 \mathrm{~m}$ \\
$\mathrm{Y}$ & $9.925 .085 \mathrm{~m}$ & $9.926 .081 \mathrm{~m}$ \\
$\mathrm{Z}$ & $60,391 \mathrm{~m}$ & $122,477 \mathrm{~m}$ \\
\hline \multicolumn{3}{c}{ Jumlah Titik : 4.594 }
\end{tabular}

Tabel 6. Statistik data EOM Pit C

\begin{tabular}{lrr}
\hline \multicolumn{3}{c}{ Pit C } \\
\hline Titik & Minimum & Maksimum \\
\hline $\mathrm{X}$ & $507178,4 \mathrm{~m}$ & $508224,3 \mathrm{~m}$ \\
$\mathrm{Y}$ & $9.925 .279 \mathrm{~m}$ & $9.926 .153 \mathrm{~m}$ \\
$\mathrm{Z}$ & $47,579 \mathrm{~m}$ & $131,156 \mathrm{~m}$ \\
\hline \multicolumn{3}{c}{ Jumlah Titik :5.296 } \\
\hline
\end{tabular}

Tabel 4, 5, dan 6 diatas menampilkan statistik koordinat pada masing-masing pit potongan, yaitu koordinat $\mathrm{X}$ minimum dan maksimum, koordinat $\mathrm{Y}$ minimum dan maksimum, koordinat $\mathrm{Z}$ minimum dan maksimum dan jumlah seluruh titik koordinat.

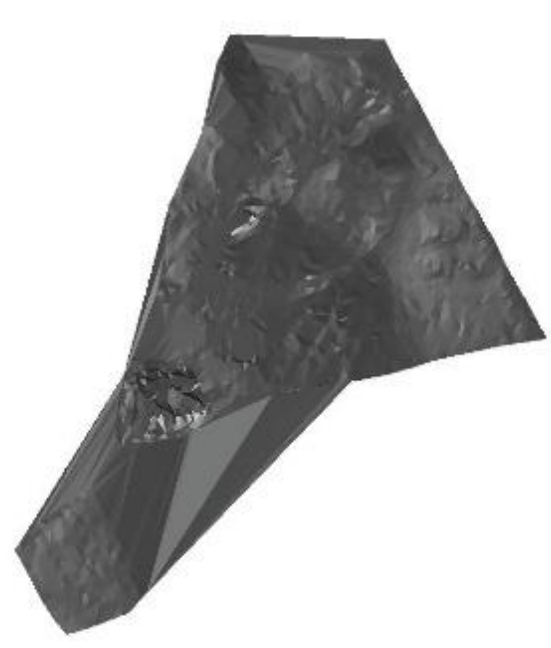

(a)

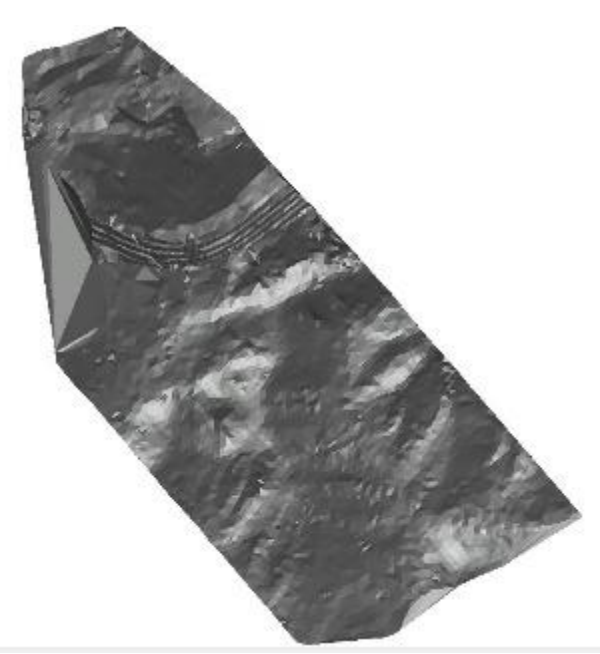

(b) 


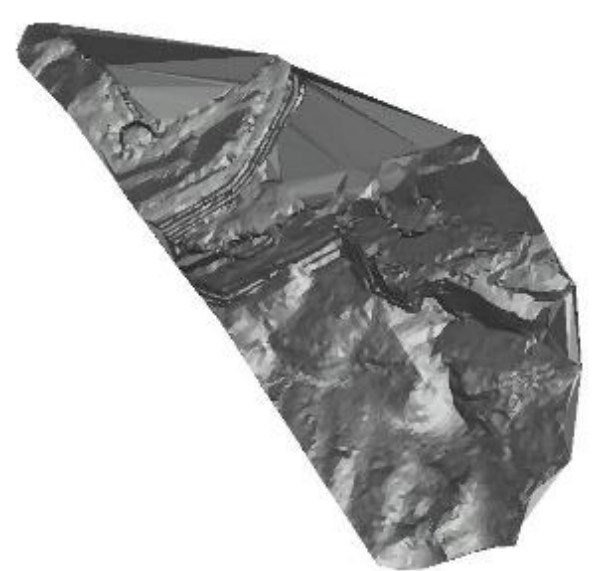

(c)

Gambar 4. Tampilan DTM Natural AutoCAD Civil 3D

Gambar 4 memperlihatkan tampilan hasil bentukan DTM natural pada perangkat lunak AutoCAD Civil 3D, dapat dilihat pada gambar tersebut bahwa tampilan hasil bentukan DTM natural pada perangkat lunak AutoCAD Civil $3 D$ tidak memiliki warna ketinggian.

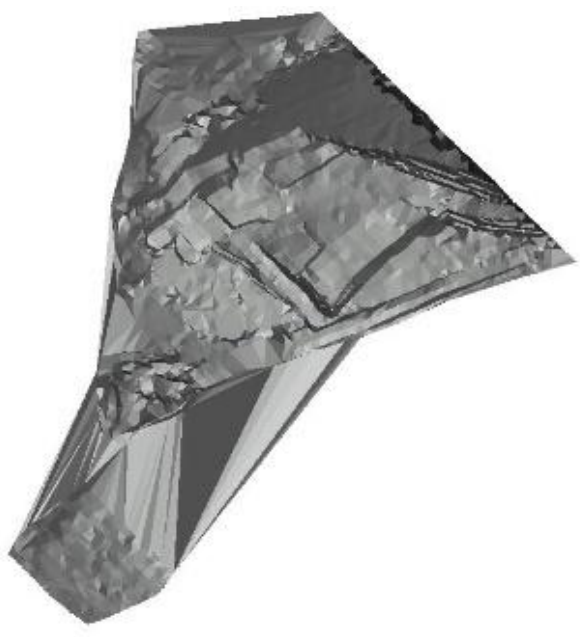

(a)

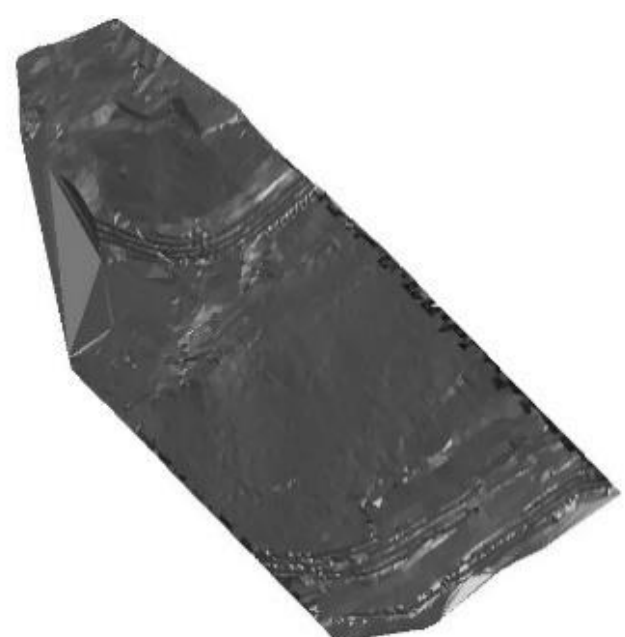

(b)

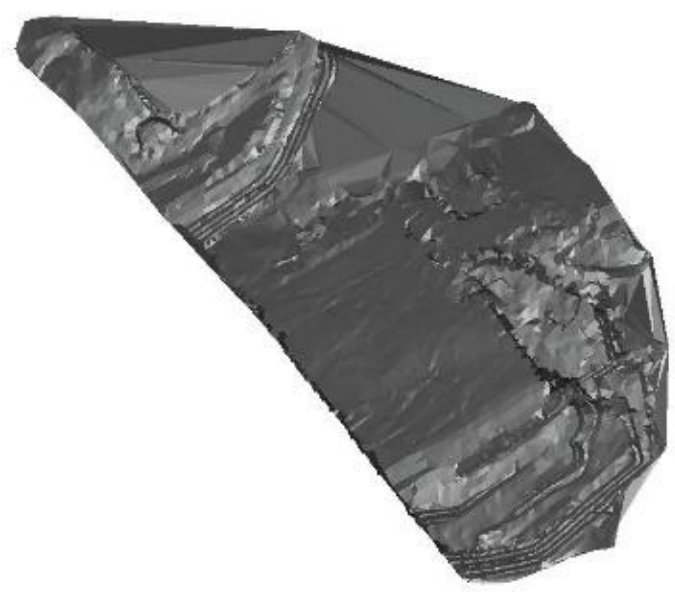

(c)

Gambar 5. Tampilan DTM EOM AutoCAD Civil 3D 
Gambar 5 memperlihatkan tampilan hasil bentukan DTM EOM pada perangkat lunak AutoCAD Civil 3D, dapat dilihat pada gambar tersebut bahwa tampilan hasil bentukan DTM EOM pada perangkat lunak AutoCAD Civil $3 D$ tidak memiliki warna ketinggian.

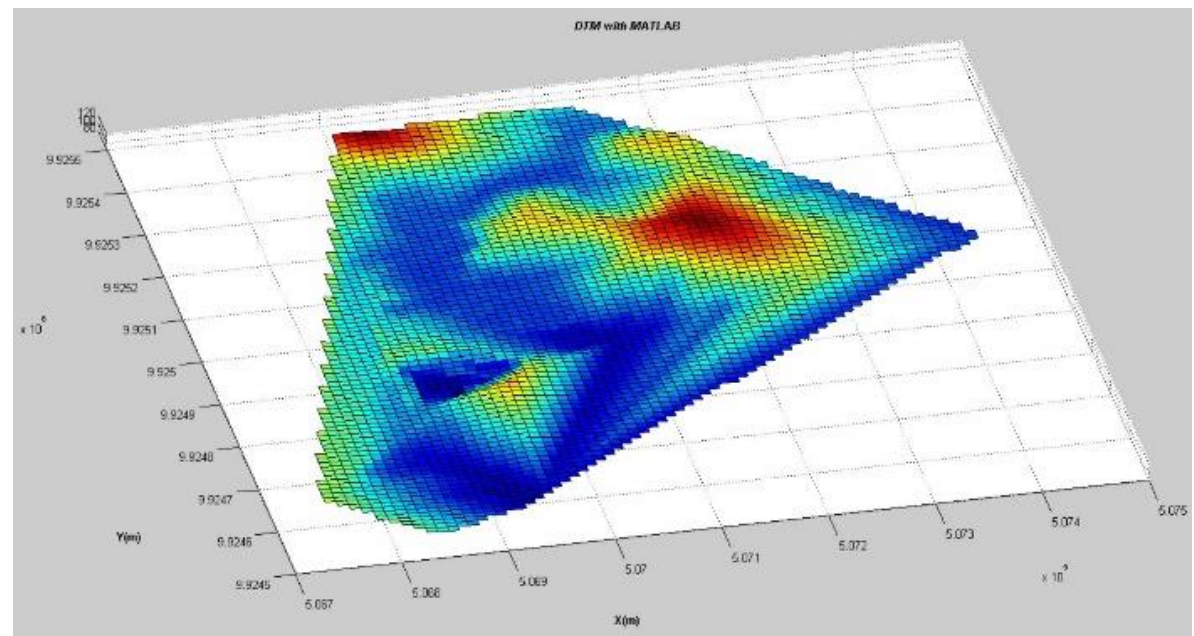

(a)

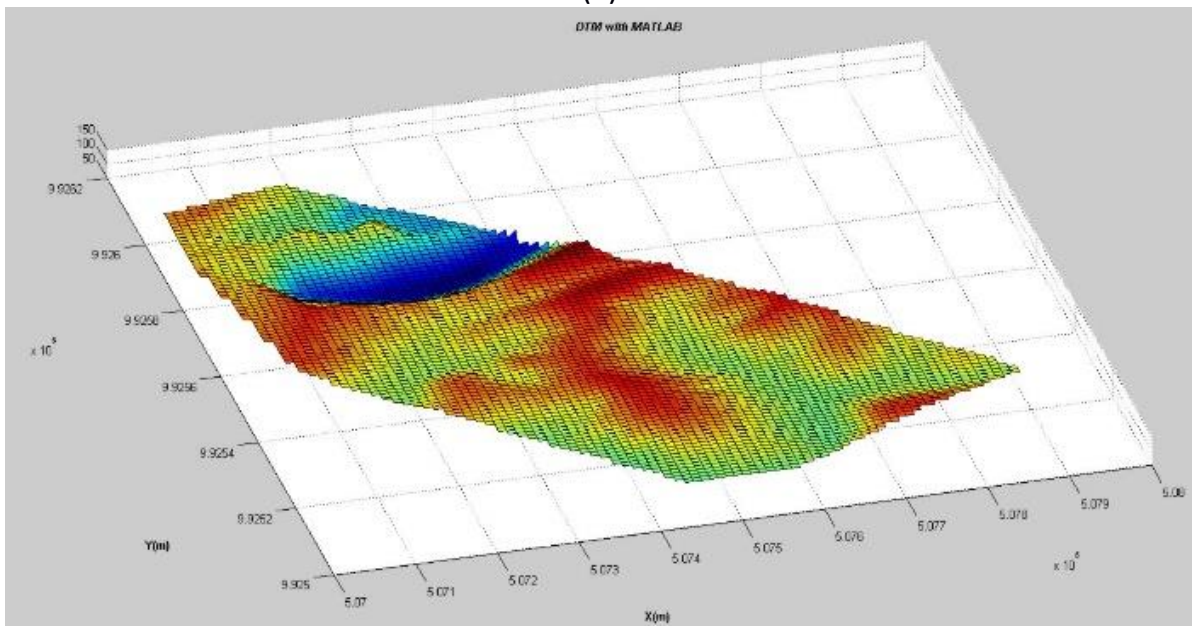

(b)



(c)

Gambar 6. Tampilan DTM Natural Matlab

(Keterangan: notasi titik “.” Pada label diatas adalah sebagai koma “,”) 
Gambar 6 memperlihatkan tampilan DTM natural hasil bentukan perangkat lunak Matlab, dapat dilihat pada gambar tersebut bahwa tampilan DTM natural hasil bentukan perangkat lunak Matlab memiliki warna ketinggian dan juga memiliki label koordinat X dan Y.

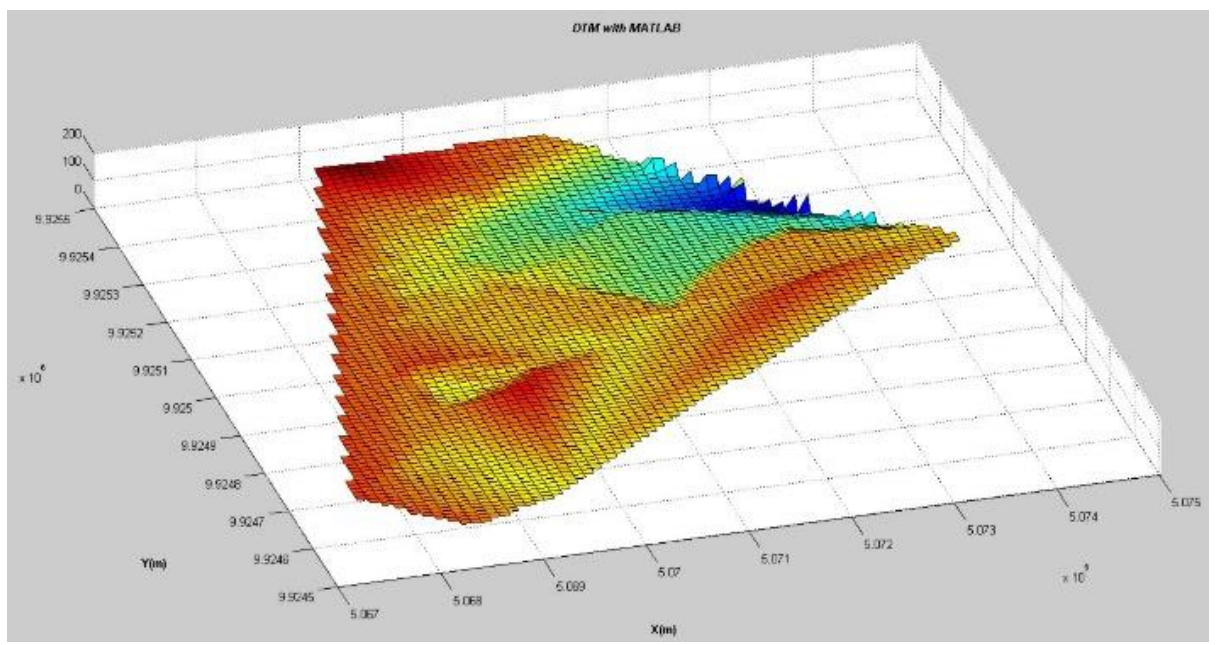

(a)

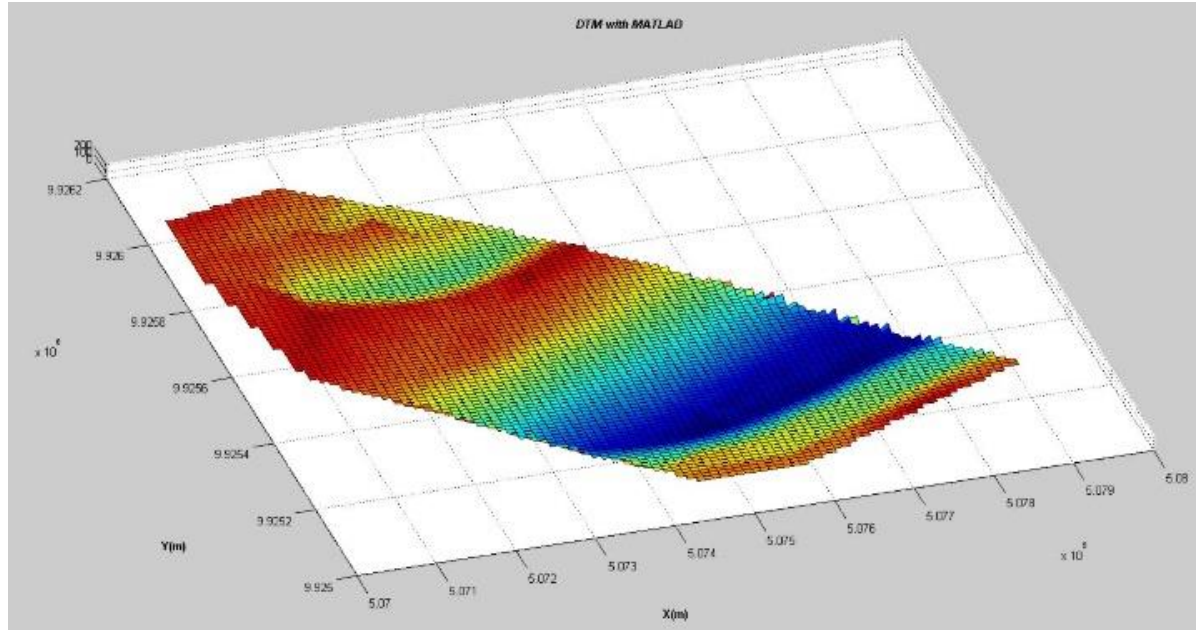

(b)



(c)

Gambar 7. Tampilan DTM EOM Matlab

(Keterangan: notasi titik “.” Pada label diatas adalah sebagai koma “,”) 
Gambar 7 memperlihatkan tampilan DTM EOM hasil bentukan perangkat lunak Matlab, dapat dilihat pada gambar tersebut bahwa tampilan DTM EOM hasil bentukan perangkat lunak Matlab memiliki warna ketinggian dan juga memiliki label koordinat X dan Y.

Pada penelitian kali ini dilakukan perhitungan volume bersih galian dan timbunan (net volume) pit A, pit B dan pit $\mathrm{C}$ dengan menggunakan metode borrow pit dan trapezoidal pada perangkat lunak AutoCAD Civil 3D, pada penelitian kali ini diberikan 2 perlakuan yaitu dengan merubah interval section pada perhitungan metode Trapezoidal dan interval grid pada perhitungan metode Borrow Pit untuk mengetahui pengaruh besar kecilnya nilai interval grid dan interval section terhadap hasil perhitungan volume, pada perhitungan metode Trapezoidal digunakan 2 interval section yaitu 10 meter dan 25 meter, penggunaan/pemilihan nilai interval section tersebut berdasarkan pengujian sebelumnya bahwa jika menggunakan nilai interval section diluar nilai tersebut perubahan nilai volume tidak terlalu signifikan dan jika interval section lebih dari 25 meter hasil perhitungan volume akan sangat tidak teliti, begitu juga pada perhitungan metode Borrow Pit, pada metode perhitungan ini menggunakan interval grid 5, 10, dan 15 meter, penggunaan/pemilihan nilai interval section tersebut berdasarkan pengujian sebelumnya bahwa jika menggunakan nilai interval grid diluar nilai tersebut perubahan nilai volume tidak terlalu signifikan dan jika interval grid lebih dari 15 meter hasil perhitungan akan sangat tidak teliti.berikut adalah hasil perhitungan volume bersih galian dan timbunan (net volume) dengan menggunakan metode borrow pit dan trapezoidal pada perangkat lunak AutoCAD Civil $3 D$ :

Pada perhitungan volume bersih galian dan timbunan (net volume) menggunakan metode borrow pit dihasilkan nilai volume yang beragam yang disebabkan oleh diberikannya perlakuan dengan merubah nilai interval grid dengan nilai 5 meter, 10 meter, dan 15 meter yang dapat dilihat pada tabel 7 berikut:

Tabel 7 Hasil Perhitungan Volume Metode Borrow Pit

\begin{tabular}{rcr}
\hline Pit & Interval Grid $(\mathrm{m})$ & Volume $\left(\mathrm{m}^{3}\right)$ \\
\hline Pit A & 5 & $2.854 .470,37$ \\
Pit A & 10 & $2.811 .065,93$ \\
Pit A & 15 & $27.53 .896,47$ \\
Pit B & 5 & $12.205 .051,3$ \\
Pit B & 10 & $12.074 .563,8$ \\
Pit B & 15 & $11.918 .374,4$ \\
Pit C & 5 & $11.928 .013,1$ \\
Pit C & 10 & $11.824 .952,3$ \\
Pit C & 15 & 11.710 .788 \\
\hline
\end{tabular}

Pada perhitungan volume bersih galian dan timbunan (net volume) menggunakan metode trapezoidal dihasilkan nilai volume yang beragam yang disebabkan oleh diberikannya perlakuan dengan merubah nilai interval section dengan nilai 10 meter dan 25 meter yang dapat dilihat pada tabel 8 berikut:

Tabel 8 Hasil Perhitungan Volume Metode Trapezoidal

\begin{tabular}{rlcr}
\hline No. & Pit & Interval Section $(\mathrm{m})$ & Volume $\left(\mathrm{m}^{3}\right)$ \\
\hline 1 & Pit A & 10 & $2.875 .537,91$ \\
2 & Pit A & 25 & $2.836 .702,68$ \\
3 & Pit B & 10 & $12.273 .643,6$ \\
4 & Pit B & 25 & $12.236 .064,88$ \\
5 & Pit C & 10 & $11.983 .517,72$ \\
6 & Pit C & 25 & $11.994 .103,69$ \\
\hline
\end{tabular}

Pada perhitungan volume manual dengan metode borrow pit pada perangkat lunak Matlab dengan menggunakan nilai interval grid 10, yaitu sesuai dengan interval atau jarak pengambilan data. Tabel 9 adalah hasil perhitungan volume manual dengan metode borrow pit pada perangkat lunak Matlab. 
Tabel 9 Hasil Perhitungan Volume Metode Trapezoidal

\begin{tabular}{rlcl}
\hline No. & Pit & Interval Grid $(\mathrm{m})$ & Volume $\left(\mathrm{m}^{3}\right)$ \\
\hline 1 & Pit A & 10 & 2.885 .800 \\
2 & Pit B & 10 & 12.272 .818 \\
3 & Pit C & 10 & 11.976 .905 \\
\hline
\end{tabular}

Pada penelitian kali ini analisa yang dilakukan adalah dengan menghitung persentase selisih perhitungan volume bersih galian dan timbunan (net volume) antara masing-masing metode pada perangkat lunak AutoCAD Civil $3 D$ terhadap hasil hitungan manual pada perangkat lunak Matlab, kemudian nilai persentase selisih tersebut akan dibandingkan dengan toleransi ASTM (American Society for Testing and Material) yaitu batas maksimal prosentase selisih hasil perhitungan volume adalah sebesar 2,78\%. Berikut adalah tabel persentase selisih volume antara metode borrow pit pada perangkat lunak AutoCAD Civil $3 D$ terhadap nilai acuan dan metode borrow pit pada perangkat lunak AutoCAD Civil $3 D$ terhadap nilai acuan.

Tabel 10 Hasil Perhitungan dan Selisih Volume Metode Borrow Pit terhadap Perhitungan Manual

\begin{tabular}{lrrrrr}
\hline Pit (1) & $\begin{array}{c}\text { Interval } \\
\text { Grid }(\mathrm{m}) \\
(2)\end{array}$ & Volume $\left(\mathrm{m}^{3}\right)(3)$ & $\begin{array}{c}\text { Volume Manual } \\
\text { Matlab }\left(\mathrm{m}^{3}\right)(4)\end{array}$ & $\begin{array}{c}\text { Selisih } \\
\left(\mathrm{m}^{3}\right)(5)\end{array}$ & $\begin{array}{c}\text { Persentase }(\%) \\
(6)\end{array}$ \\
\hline Pit A & 5 & $2.854 .470,4$ & 2.885 .800 & $31.329,63$ & 1,086 \\
Pit A & 10 & $2.811 .065,9$ & 2.885 .800 & $74.734,07$ & 2,590 \\
Pit A & 15 & $2.753 .896,5$ & 2.885 .800 & $131.903,5$ & 4,571 \\
Pit B & 5 & 12.205 .051 & 12.272 .818 & $67.766,69$ & 0,552 \\
Pit B & 10 & 12.074 .564 & 12.272 .818 & $198.254,2$ & 1,615 \\
Pit B & 15 & 11.918 .374 & 12.272 .818 & $354.443,7$ & 2,888 \\
Pit C & 5 & 11.928 .013 & 11.976 .905 & $48.891,94$ & 0,408 \\
Pit C & 10 & 11.824 .952 & 11.976 .905 & $151.952,7$ & 1,269 \\
Pit C & 15 & 11.710 .788 & 11.976 .905 & 266.117 & 2,222 \\
\hline \multicolumn{4}{c}{ (Keterangan: nilai kolom (6) didapatkan dari kolom (5) dibagi kolom (4) dikali 100) }
\end{tabular}

Pada tabel 10 dapat dilihat bahwa terdapat 2 perhitungan volume bersih galian dan timbunan (net volume) yang tidak masuk toleransi ASTM, yaitu pada pit A dan pit B dengan interval grid 15 meter, yaitu dengan nilai persentase selisih volume $4,571 \%$ dan $2,888 \%$.

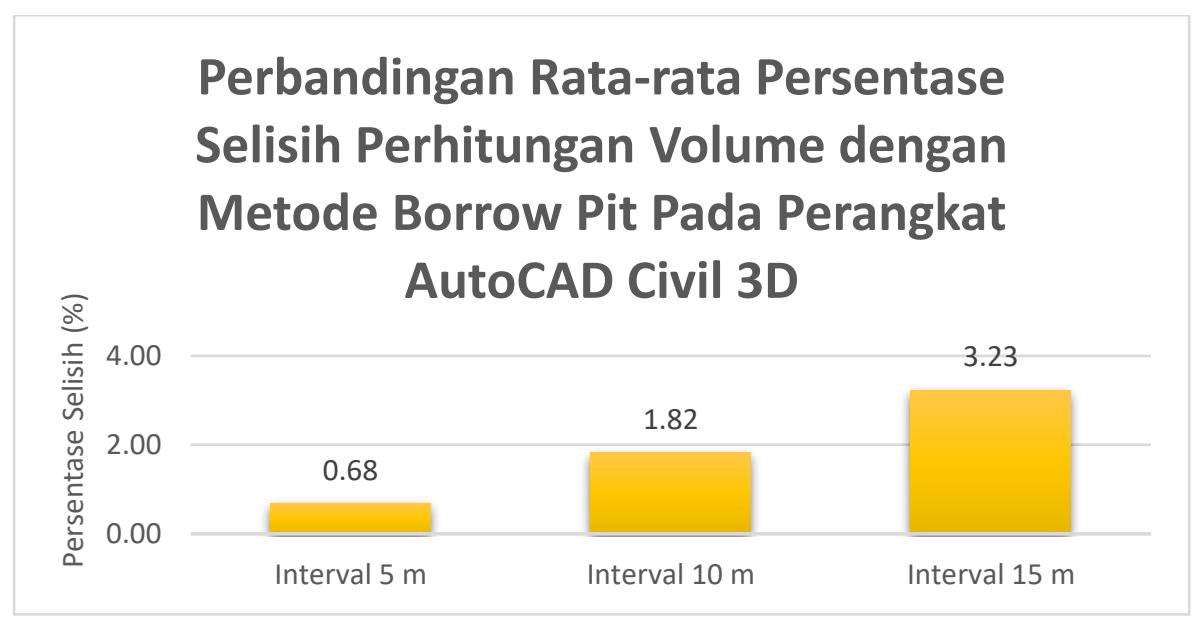

Gambar 8. Perbandingan Rata-rata Persentase Selisih Perhitungan Volume dengan Metode Borrow Pit Pada Perangkat AutoCAD Civil 3D

(Keterangan: notasi titik “.” Pada label diatas adalah sebagai koma “,”) 
Gambar 8 menunjukan gambar tabel histogram Perbandingan Rata-rata Persentase Selisih Perhitungan Volume dengan Metode Borrow Pit Pada Perangkat AutoCAD Civil 3D, dapat dilihat bahwa nilai interval grid sangat mempengaruhi hasil perhitungan volume, semakin kecil interval grid yang dibuat maka hasil perhitungan akan semakin mendekati nilai acuan begitu pula sebaliknya semakin besar interval grid yang dibuat maka hasil perhitungan akan semakin menjauhi nilai acuan.

Tabel 11. Hasil Perhitungan Dan Selisih Volume Metode Trapezoidal Terhadap Perhitungan Manual

\begin{tabular}{lrrrrr}
\hline Pit (1) & $\begin{array}{c}\text { Interval } \\
\text { Section }(\mathrm{m}) \\
(2)\end{array}$ & Volume $\left(\mathrm{m}^{3}\right)(3)$ & $\begin{array}{r}\text { Volume Manual } \\
\text { Matlab }\left(\mathrm{m}^{3}\right)(4)\end{array}$ & Selisih $\left(\mathrm{m}^{3}\right)(5)$ & $\begin{array}{c}\text { Persentase (\%) } \\
(6)\end{array}$ \\
\hline Pit A & 10 & $2.875 .537,91$ & 2.885 .800 & $10.262,09$ & 0,356 \\
Pit A & 25 & $2.836 .702,68$ & 2.885 .800 & $49.097,32$ & 1,701 \\
Pit B & 10 & $12.273 .643,6$ & 12.272 .818 & 825,6 & 0,007 \\
Pit B & 25 & $12.236 .064,88$ & 12.272 .818 & $36.753,12$ & 0,299 \\
Pit C & 10 & $11.983 .517,72$ & 11.976 .905 & $6.612,72$ & 0,055 \\
Pit C & 25 & $11.994 .103,69$ & 11.976 .905 & $17.198,69$ & 0,144 \\
\hline \multicolumn{5}{c}{ (Keterangan: nilai kolom (6) didapatkan dari kolom (5) dibagi kolom (4) dikali 100) } \\
\end{tabular}

Pada tabel 11 dapat dilihat bahwa seluruh hasil perhitungan volume bersih galian dan timbunan (net volume) masuk toleransi ASTM. Gambar 9 menunjukan gambar tabel histogram Perbandingan Rata-rata Persentase Selisih Perhitungan Volume dengan Metode Trapezoidal Pada Perangkat AutoCAD Civil 3D, dapat dilihat bahwa nilai interval section sangat mempengaruhi hasil perhitungan volume, semakin kecil interval section yang dibuat maka hasil perhitungan akan semakin mendekati nilai acuan begitu pula sebaliknya semakin besar interval section yang dibuat maka hasil perhitungan akan semakin menjauhi nilai acuan.

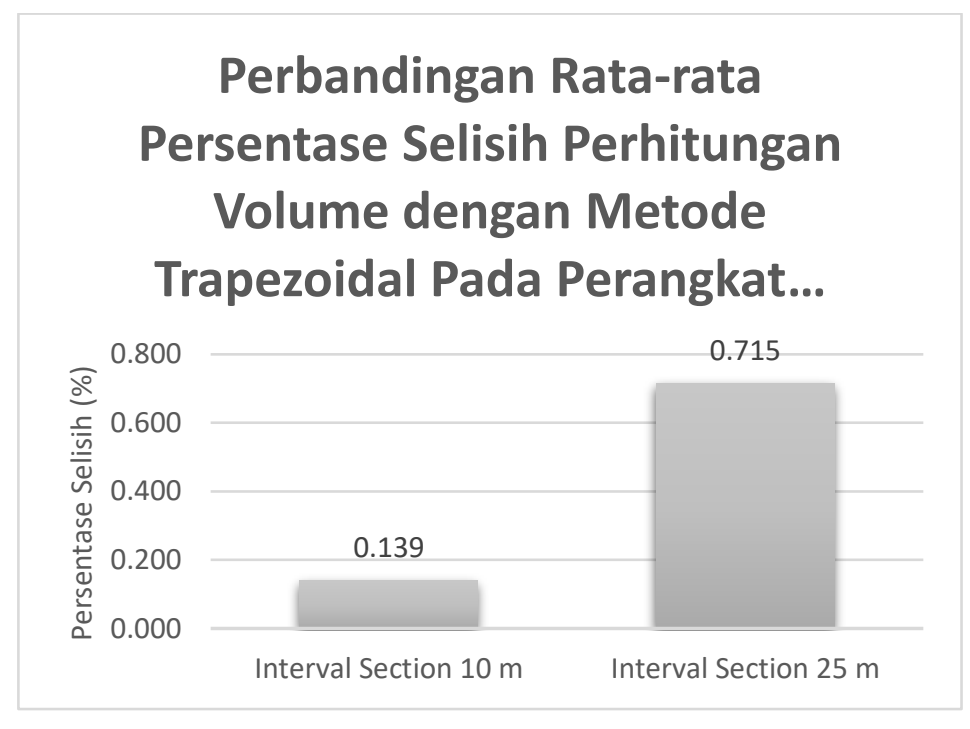

Gambar 9. Perbandingan Rata-rata Persentase Selisih Perhitungan Volume dengan Metode Trapezoidal Pada Perangkat AutoCAD Civil 3D

(Keterangan: notasi titik “.” Pada label diatas adalah sebagai koma “,”)

Gambar 10 menunjukan gambar tabel histogram Perbandingan Rata-rata Persentase Selisih Perhitungan Volume dengan Metode Borrow Pit dan Trapezoidal Pada Perangkat AutoCAD Civil 3D, dapat dilihat bahwa 
rata-rata persentase selisih volume metode trapezoidal lebih kecil dibandingkan metode borrow pit, hal ini disebabkan karena pada perhitungan metode borrow pit dengan interval grid 10 meter dan 15 meter memiliki persentase selisih volume yang besar, sehingga rata-rata persentase selisih volume pada metode borrow pit menjadi besar.

\section{Perbandingan Rata-rata Persentase Selisih Perhitungan Volume Pada Perangkat Lunak Perhitungan Volume}

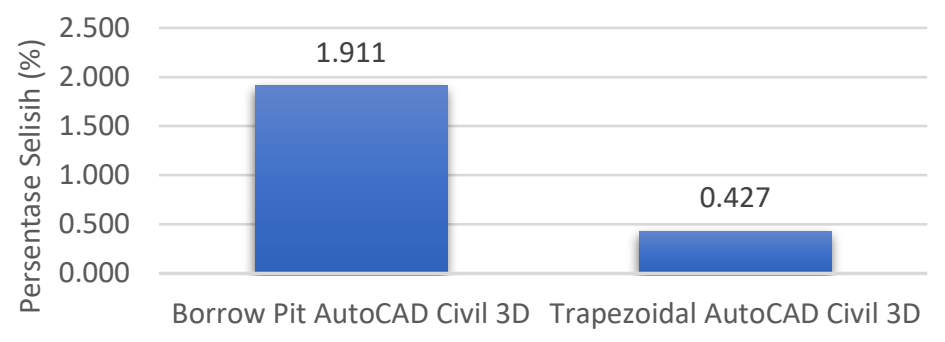

Gambar 10. Perbandingan Rata-rata Persentase Selisih Perhitungan Volume dengan Metode Borrow Pit dan

Trapezoidal Pada Perangkat AutoCAD Civil 3D

(Keterangan : notasi titik “.” Pada label diatas adalah sebagai koma “,”)

\section{Kesimpulan}

Pada hasil pembahasan diatas terdapat 2 persentase perhitungan yang tidak masuk toleransi ASTM yaitu pada pit A dan pit B dengan interval grid 15 meter, yaitu dengan nilai persentase selisih volume $4,571 \%$ dan 2,888\%. Pada perhitungan volume metode borrow pit nilai interval grid sangat mempengaruhi hasil perhitungan volume, semakin kecil interval grid yang dibuat maka hasil perhitungan akan semakin mendekati nilai acuan. Pada perhitungan metode trapezoidal nilai interval section sangat mempengaruhi hasil perhitungan volume, semakin kecil interval section yang dibuat maka hasil perhitungan akan semakin mendekati nilai acuan. Pada hasil perhitungan volume metode borrow pit dan trapezoidal, metode trapezoidal memiliki nilai persentase selisih volume lebih kecil dibandingkan metode borrow pit.

\section{Ucapan Terimakasih}

Penulis. mengucapkan terima kasih kepada PT. Anugerah Bara Kaltim yang telah memberikan dukungan berupa data koordinat natural dan eom sehingga pelaksanaan penelitian dapat berjalan dengan lancar.

\section{Daftar Pustaka}

Agor, R. (1982). A Text Book of Surveying \& Levelling. Delhi, India : Khana Publisher.

Away, G. A. (2006). The Shotcut of Matlab Programming, Bandung : Informatika.

Basuki, S. (2011). Ilmu Ukur Tanah (Edisi Revisi). Yogyakarta: Gadjah Mada University Press.

Brinker, R. C. (1986). Dasar Dasar Pengukuran Tanah jilid 1. Jakarta: penerbit Erlangga,139-146.

Dipokusumo. dkk. (1983). Dasar Teori Model Terrain Digital. (http://www.scribd.com/doc/135113289/Dasar-TeoriModel-Terrain-Digital diakses pada: 11 September 2019.)

Geodis-Ale. (2012). Calculation of Volume. http://www.geodis-ale.com/ (Diakses pada 7 September 2019).

Irvine W. (1995). Surveying For Construction. UK: UK Higher Education Engineering, Civil Engineering.

Lama A. R. (2018). Analisis Ketelitian Perhitungan Volume Galian Menggunakan Data Gridding Dan Tanpa Gridding Pada Pekerjaan Bendungan. Malang: Program Studi Teknik Geodesi Fakultas Teknik, Institut Teknologi Nasional Malang.

Linkwitz. (1970). Dasar Teori Model Terrain Digital. Akses pada: 8 September 2019. digilib.itb.ac.id/files/...jbptitbpp- 
gdl-diponawang-33911-62009ta-5.pdf

Nurjati, Chatarinas. (2004). Modul Ajar Ilmu Ukur Tanah I. Surabaya: Teknik Geodesi ITS-FTSP.

Nuryadi, dkk. (2017). Dasar-dasar Statistik Penelitian. Yogyakarta: Sibuku Media

Oktavian A. (2008). Analisis Perbandinag software surpac vision v4.1-j dan surfer 8.0 pada perhitungan volume galian dan timbunan tambang. Surabaya: Teknik Geomatika ITS

Purwaamijaya, I. M. (2008). Teknik Survey dan Pemetaan jilid 3 untuk SMK. Direktorat Pembinaan Sekolah Menengah Kejuruan : Departemen Pendidikan Nasional.

Purwohardjo, Umaryono U. (1986). Pengukuran Topografi. Bandung : Jurusan Teknik Geodesi ITB.

Siregar, S. 2013. Statistik Parametrik untuk Penelitian Kuantitatif. Jakarta: Bumi Aksara.

Zhilin, Li, Qing Zhu, Christoper Gold. (2005). Digital Terrain Model Principles and Methodology. Washington : D.C., CRC Press 